\title{
Is there any association between Sarcoidosis and infectious agents?: a systematic review and meta-analysis
}

\author{
Tiago Esteves $^{1 *}$, Gloria Aparicio ${ }^{2}$ and Vicente Garcia-Patos ${ }^{1,2}$
}

\begin{abstract}
Background: During the last few years, investigators have debated the role that infectious agents may have in sarcoidosis pathogenesis. With the emergence of new molecular biology techniques, several studies have been conducted; therefore, we performed a meta-analysis in order to better explain this possible association.
\end{abstract}

Methods: This review was conducted in accordance with the Preferred Reporting Items for Systematic Reviews and Meta-Analyses (PRISMA) statement from the Cochrane collaboration guidelines. Four different databases (Medline, Scopus, Web of Science, and Cochrane Collaboration) were searched for all original articles published from 1980 to 2015. The present meta-analysis included case-control studies that reported the presence of microorganisms in samples of patients with sarcoidosis using culture methods or molecular biology techniques. We used a random effects or a fixed-effect model to calculate the odds ratio (OR) and 95\% confidence intervals (Cl). Sensitivity and subgroup analyses were performed in order to explore the heterogeneity among studies.

Results: Fifty-eight studies qualified for the purpose of this analysis. The present meta-analysis, the first, to our knowledge, in evaluation of all infectious agents proposed to be associated with sarcoidosis and involving more than 6000 patients in several countries, suggests an etiological link between Propionibacterium acnes and sarcoidosis, with an OR of 18.80 ( $95 \% \mathrm{Cl} 12.62,28.01)$. We also found a significant association between sarcoidosis and mycobacteria, with an OR of 6.8 (95\% Cl 3.73, 12.39). Borrelia (OR 4.82; 95\% Cl 0.98, 23.81), HHV-8 (OR 1.47; 95\% $\mathrm{Cl} 0.02,110.06)$ as well as Rickettsia helvetica, Chlamydia pneumoniae, Epstein-barr virus and Retrovirus, although suggested by previous investigations, were not associated with sarcoidosis.

Conclusion: This meta-analysis suggests that some infectious agents can be associated with sarcoidosis. What seems clear is that more than one infectious agent might be implicated in the pathogenesis of sarcoidosis; probably the patient's geographical location might dictate which microorganisms are more involved. Future investigations and more clinical trials are need to bring these evidences to a more global level.

Keywords: Sarcoidosis, Propionibacterium acnes, Mycobacteria, Infection, Meta-analysis

\section{Background}

Sarcoidosis is a systemic disorder of unknown origin that is characterized by the presence of non-caseating granulomas. With worldwide distribution, more than one causative agent may be implicated in its pathogenesis [1], with numerous infectious and non-infectious etiological agents having been identified [2]. Currently,

\footnotetext{
*Correspondence: tcesteves990@sapo.pt

'Department of Medicine, Universitat Autònoma de Barcelona, Passeig de la Vall d'Hebron, 119-129, 08035 Barcelona, Spain

Full list of author information is available at the end of the article
}

the focus is on infectious agents, especially species of Mycobacterium and Propionibacterium. Other infectious agents have been investigated with inconclusive or conflicting results, such as Borrelia burgdorferi, Rickettsia helvetica, Chlamydia pneumoniae, viruses, fungal infections, and Leishmania species [3-11].

There are only two relevant meta-analyses in the literature $[12,13]$, which address the causal relationship of some infectious agents in sarcoidosis. Since then, more than 20 new investigations have been published, thus adding new relevant data to the discussion. This meta- 
analysis is the first to evaluate all infectious agents that may be involved in sarcoidosis.

\section{Methods}

\section{Search strategy}

This review was conducted in accordance with the Preferred Reporting Items for Systematic Reviews and Meta-Analyses (PRISMA) statement from the Cochrane collaboration guidelines. A checklist is available (Additional file 1). Since this study was a literature review and meta-analysis of previously reported studies, ethical approval or additional consent from participants was not required. Four different databases (Medline, Scopus, Web of Science and Cochrane Database) were searched for all original articles without language restriction published from January 1980 to May 2015, using the search strategy described in online supplementary data (Additional file 2).

\section{Inclusion criteria}

The inclusion criteria were as follows: (i) the diagnosis of sarcoidosis was made according to the classical criteria: a compatible clinical and radiological picture, histopathological demonstration of non-caseating granulomas with negative stains for mycobacterium and fungi, and exclusion of other granulomatous diseases; [14] (ii) case-control studies that reported the presence of microorganisms in samples, both histological and cellular, of patients with sarcoidosis, using either culture methods (direct isolation of the organism) or molecular biology techniques (analysis of DNA, RNA or proteins); (iii) odds ratios (OR) and the corresponding confidence intervals $(\mathrm{CI})$ or sufficient information to calculate them; (iv) patients without sarcoidosis were used as a reference group.

\section{Exclusion criteria}

Studies involving other techniques (e.g. ELISA, immunohistochemistry and immunofluorescence) were excluded from the analysis.

\section{Data extraction}

First, two independent authors (T. Esteves and V. Garcia-Patos) reviewed all titles and abstracts. A second selection was based on a full-text review of potentially relevant articles and any disagreement was resolved by discussion between the three authors of this metaanalysis. A standardized data collection form was used to extract the following items: author(s), title of article, study design, year of publication, country of origin, study size, details of molecular or other techniques used.

\section{Statistical analysis and methodological quality assessment}

The measure of interest was the OR and 95\% CI calculated from each study, in order to assess the presence of microorganisms in sarcoidosis samples versus controls. Data analyses were performed using Stata Statistical Software 2015 (StataCorp LP, College Station, Texas, USA). We used a random-effects model to calculate the OR and 95\% CI from each study [15].

We assessed the heterogeneity among studies using Cochran's Q test [16], complemented by the $\mathrm{I}^{2}$-test. [17] An $\mathrm{I}^{2}$ value of $76-100 \%$ represents high heterogeneity, $51-75 \%$ moderate heterogeneity and $0-50 \%$ low or insignificant heterogeneity [17]. If the result of the Chisquare heterogeneity test was not significant $(p>0.10)$, we used the fixed-effects model described by Mantel and Haenszel [18] to calculate the pooled OR estimate. Additionally, sensitivity and subgroup analyses were performed in order to explore the heterogeneity among studies.

\section{Results}

\section{Studies included}

A total of 2465 articles were identified from the initial electronic search using the outlined search term parameters (Additional file 2). Among these, 2401 studies were excluded because they did not meet the inclusion criteria. A total of 64 articles were identified as investigating the role of infectious agents in sarcoidosis using either microbial culture or molecular methods. Six of these were later excluded since they were descriptive studies without a control group. Therefore, 58 case-control studies were qualified for the analysis according to the inclusion and exclusion criteria. Additional file 3 summarizes the study flow.

In total, the 58 studies involved 2467 samples from patients with proven sarcoidosis and 3656 samples from control patients with other non-sarcoid disorders. All studies used molecular techniques to identify the different types of infectious agents except for two, which used microbial culture in their analyses $[19,20]$.

With regard to the infectious agents investigated, 36 studies evaluated the presence of mycobacteria [2055] (Table 1), 11 evaluated $P$. acnes [19, 22, 24, 25, 31, 35, 38, 56-59] (Table 2), seven evaluated human herpesvirus-8 (HHV-8) [22, 40, 60-64] (Table 3), and six evaluated Borrelia species [4, 65-69] (Table 4). Other infectious agents were investigated in some of the studies included, but there were insufficient cases to perform a meta-analysis. Three studies evaluated the presence of Rickettsia species, and one found a strong association between Rickettsia helvetica and sarcoidosis [70] (OR 21.72; CI:1.23-384.74). The 
Table 1 Case-control studies evaluating the role of mycobacteria in sarcoidosis

\begin{tabular}{|c|c|c|c|c|c|c|c|}
\hline \multirow[t]{2}{*}{ First author/Year (Ref.) } & \multirow[t]{2}{*}{ Country } & \multirow[t]{2}{*}{ Molecular technique } & \multicolumn{2}{|c|}{ Sarcoidosis patients } & \multicolumn{2}{|c|}{ Non-sarcoidosis controls } & \multirow[t]{2}{*}{ OR $(95 \% \mathrm{Cl})$} \\
\hline & & & $\mathrm{n} / \mathrm{N}$ & Type of microorganisms & $\mathrm{n} / \mathrm{N}$ & Type of microorganisms & \\
\hline Bocart, 1992 [23] & France & $\begin{array}{l}\text { PCR of } 65 \mathrm{kDa} \text { mycobacterial } \\
\text { antigen and IS6110 }\end{array}$ & $2 / 22$ & MTBC & $0 / 22$ & - & $5.49(0.25-121.18)$ \\
\hline Hofland, 2014 [20] & Netherlands & $\begin{array}{l}\text { NAAT for Mycobacteria } \\
\text { and Culture }\end{array}$ & $0 / 32$ & - & $2 / 86$ & 1 MTBC, 1NTM & $0.52(0.02-11.13)$ \\
\hline Robinson, 2013 [24] & USA & $\begin{array}{l}\text { PCR for } 165 \text { rDNA, hsp65 } \\
\text { and rpoB }\end{array}$ & $2 / 30$ & NTM & $1 / 30$ & NTM & $2.07(0.18-24.15)$ \\
\hline Oswald-Richter, 2012 [25] & USA & MALDI-IMS for ESAT-6 & $5 / 15$ & Mycobacterium spp & $0 / 4$ & - & $\begin{array}{l}4.71 \\
(0.21-104.49)\end{array}$ \\
\hline Svendsen, 2011 [26] & Denmark & $\begin{array}{l}\text { BD ProbeTec IS6110 } \\
\text { amplification }\end{array}$ & $1 / 52$ & MTBC & $0 / 50$ & - & $\begin{array}{l}2.94 \\
(0.12-73.93)\end{array}$ \\
\hline Mootha, 2010 [27] & India & $\begin{array}{l}\text { PCR of } 65 \mathrm{kDa} \text { mycobacterial } \\
\text { antigen and IS6110 }\end{array}$ & $13 / 27$ & 10 MTBC, 3 NTM & $2 / 40$ & NTM & $\begin{array}{l}17.64 \\
(3.53-88.25)\end{array}$ \\
\hline Zhou, 2008 [28] & China & $\begin{array}{l}\text { Real-time PCR of IS986 } \\
\text { and human } \beta \text {-blobin gene }\end{array}$ & $20 / 104$ & MTBC & $7 / 55$ & MTBC & $\begin{array}{l}1.63 \\
(0.64-4.14)\end{array}$ \\
\hline Dubaniewicz, 2006 [29] & Poland & $\begin{array}{l}\text { BD ProbeTec IS6110 } \\
\text { amplification }\end{array}$ & $3 / 50$ & MTBC & $0 / 10$ & - & $1.55(0.07-32.27)$ \\
\hline Fite, 2006 [30] & Spain & $\begin{array}{l}\text { PCR of IS6110 and Southern } \\
\text { blot hybridisation }\end{array}$ & $9 / 23$ & MTBC & $1 / 23$ & MTBC & $14.14(1.61-124.11)$ \\
\hline Yasuhara, 2005 [31] & Japan & PCR of IS6110 & $0 / 6$ & - & $0 / 6$ & - & - \\
\hline Song, 2005 [32] & USA & PCR of MTB 165 rRNA & $6 / 16$ & MTBC & $0 / 16$ & - & $20.43(1.04-401.67)$ \\
\hline Marcoval, 2005 [33] & Spain & NAAT for rRNA of MTBC & $0 / 35$ & - & $0 / 39$ & - & - \\
\hline Yu-Yun Lee, 2002 [34] & Taiwan & $\begin{array}{l}\text { Nested PCR for } \\
\text { mycobacterial hsp65 DNA }\end{array}$ & $7 / 21$ & NTM & $0 / 16$ & - & $17.07(0.89-325.59)$ \\
\hline Drake, 2002 [21] & USA & $\begin{array}{l}\text { PCR of } 16 \mathrm{~S} \text { rRNA, } \\
\text { rpoB and IS6110 }\end{array}$ & $15 / 25$ & 11 MTBC, 3 NTM, 1 both & $0 / 25$ & - & $75.29(4.12-1377.06)$ \\
\hline Gazouli, 2002 [22] & Greece & $\begin{array}{l}\text { PCR of IS6110/IS1245/IS900/IS901, } \\
16 \mathrm{~S} \text { rRNA, MPB64 and mtp40 }\end{array}$ & $33 / 46$ & MTBC & $0 / 20$ & - & $101.74(5.74-1804.62)$ \\
\hline Eish, 2002 [35] & Japan & PCR of IS6110/IS900 & $5 / 108$ & MTBC & $2 / 86$ & MTBC & $2.04(0.39-10.78)$ \\
\hline Klemen, 2000 [36] & Austria & $\begin{array}{l}\text { PCR of IS6110 and } \\
\text { mycobacterial chaperonin }\end{array}$ & $3 / 4$ & NTM & $0 / 39$ & - & $184.33(6.26-5425.48)$ \\
\hline Li, 1999 [37] & USA & $\begin{array}{l}\text { PCR of } 65 \mathrm{kDa} \text { mycobacterial } \\
\text { antigen and RFLP analysis }\end{array}$ & $16 / 20$ & 2 MTBC, 14 NTM & $0 / 20$ & - & $150.33(7.54-2997.83)$ \\
\hline Ishige, 1999 [38] & Japan & PCR of IS6110 & $3 / 15$ & MTBC & $1 / 15$ & MTBC & $3.50(0.32-38.23)$ \\
\hline Wilsher, 1998 [39] & NZ & $\begin{array}{l}\text { PCR of IS6110, nested PCR } \\
\text { to amplify } 85 \text { bp sequence } \\
\text { within the } 123 \text { bp product }\end{array}$ & $0 / 31$ & - & $0 / 10$ & - & - \\
\hline Di Alberti, 1997 [40] & Italy & Heminested PCR for $16 \mathrm{~S}$ rRNA & $17 / 38$ & 4 NTM, 13 Mycobacterium spp & $39 / 113$ & 39 Mycobacterium spp & $1.54(0.73-3.24)$ \\
\hline
\end{tabular}


Table 1 Case-control studies evaluating the role of mycobacteria in sarcoidosis (Continued)

\begin{tabular}{|c|c|c|c|c|c|c|c|}
\hline Vokurka, 1997 [41] & France & PCR of IS6110 and DR region & $0 / 15$ & - & $0 / 27$ & - & - \\
\hline Ozcelik, 1997 [42] & Turkey & PCR of IS6110 & $5 / 11$ & MTBC & $2 / 15$ & MTBC & $5.42(0.81-36.36)$ \\
\hline Popper, 1997 [43] & Austria & $\begin{array}{l}\mathrm{PCR} \text { of } 65 \mathrm{kDa} \\
\text { mycobacterial antigen } \\
\text { and IS6110 }\end{array}$ & $11 / 35$ & NTM & $0 / 39$ & - & $37.08(2.09-657.90)$ \\
\hline El-Zaatari, 1996 [44] & USA & $\begin{array}{l}\text { PCR of IS900/IS902, } \\
\text { MAC-specific PCR assay } \\
\text { and Western blot }\end{array}$ & $7 / 7$ & NTM & $13 / 38$ & NTM & $28.33(1.50-534.74)$ \\
\hline Fidler, 1993 [45] & UK & $\begin{array}{l}\text { PCR of } 65 \mathrm{kDa} \\
\text { mycobacterial antigen } \\
\text { and IS6110 }\end{array}$ & $7 / 16$ & MTBC & $1 / 16$ & MTBC & $11.67(1.23-110.95)$ \\
\hline Thakker, 1992 [46] & UK & PCR of groEL & $1 / 14$ & MTBC & $1 / 11$ & MTBC & $0.77(0.04-13.87)$ \\
\hline Gerdes, 1992 [47] & Germany & PCR of 165 rDNA & $0 / 14$ & - & $0 / 10$ & - & - \\
\hline Mitchell, 1992 [48] & UK & $\begin{array}{l}\text { Mycobacterial rRNA } \\
\text { detection by liquid } \\
\text { phase hybridisation }\end{array}$ & $5 / 5$ & MTBC & $0 / 5$ & - & $121(2.02-7259.18)$ \\
\hline Saboor, 1992 [49] & UK & $\begin{array}{l}\text { PCR of IS986/IS6110 } \\
\text { and groEL }\end{array}$ & $14 / 20$ & 10 MTBC, 4 NTM & $5 / 22$ & 3 MTBC, 2 NTM & $7.93(1.99-31.59)$ \\
\hline Lisby, 1993 [50] & Denmark & Nested PCR for IS900 & $0 / 18$ & - & $0 / 18$ & - & - \\
\hline Grosser, 1999 [51] & Germany & PCR of IS986/IS6110 & $35 / 65$ & MTBC & $1 / 34$ & MTBC & $38.50(4.96-298.57)$ \\
\hline Vago, 1998 [52] & Italy & PCR of IS6110 & $2 / 30$ & MTBC & $0 / 17$ & - & $3.07(0.14-67.75)$ \\
\hline Richter, 1996 [53] & Germany & $\begin{array}{l}\text { PCR of mycobacterial } \\
16 S \text { rDNA }\end{array}$ & $1 / 24$ & MTBC & $3 / 57$ & MTBC & $0.78(0.08-7.93)$ \\
\hline Ghossein, 1994 [54] & USA & $\begin{array}{l}\mathrm{PCR} \text { of } 65 \mathrm{kDa} \\
\text { mycobacterial antigen }\end{array}$ & $0 / 10$ & - & $0 / 10$ & - & - \\
\hline Cannone, 1997 [55] & Italy & PCR of IS6110 & $2 / 30$ & MTBC & $0 / 10$ & - & $1.84(0.08-41.62)$ \\
\hline
\end{tabular}

$n$ Mycobacteria-positive samples, $N$ total samples, $P C R$ polymerase chain reaction, $65 \mathrm{kDa}$ 65-Kilodalton mycobacteria antigen, IS6110 insertion sequence to identify Mycobacterium tuberculosis complex (MTBC), $N$ TM non-tuberculous mycobacteria, NAAT nucleic acid amplification test, 165 rDNA ribosomal DNA common to all mycobacteria, rpoB RNA polymerase $\beta$-subunit gene, MALDI-IMS matrix-assisted laser desorption ionization as a mass spectrometry imaging, ESAT-6 $6 \mathrm{kDa}$ early secretory antigenic target produced by Mycobacterium tuberculosis, IS986 insertion sequence to identify MTBC, $r R N A$ ribosomal RNA, IST245/IS900/S901/IS902 insertion sequence to identify Mycobacterium avium complex, MPB64 mycobacterial protein, mtp40 Specific primers of MTB species, RFLP restriction fragment length polymorphism DR direct repeat, groEL gene encoding $65 \mathrm{kDa}$ antigen 
Table 2 Case-control studies evaluating the role of $P$. acnes in sarcoidosis

\begin{tabular}{llllll}
\hline First author/Year (Ref.) & Country & Molecular technique & Sarcoidosis & Controls & OR (95\% Cl) \\
& & & $n / N$ & $n / N$ \\
\hline Robinson, 2013 [24] & USA & PCR for bacterial 16S rDNA & $7 / 30$ & $1 / 30$ & $8.83(1.01-76.96)$ \\
Oswald-Richter, 2012 [25] & USA & MALDI-IMS for propionibacterial proteins & $7 / 15$ & $1 / 4$ & $2.63(0.22-31.35)$ \\
Yasuhara, 2005 [31] & Japan & PCR for 16S rRNA & $2 / 6$ & $0 / 6$ & $7.22(0.28-189.19)$ \\
Gazouli, 2002 [22] & Greece & PCR for 16S rRNA & $0 / 46$ & $0 / 20$ & - \\
Eish, 2002 [35] & Japan & PCR for 16S rRNA & $93 / 108$ & $25 / 86$ & $15.13(7.39-30.99)$ \\
Ishige, 1999 [38] & Japan & Quantitative PCR for 16S rRNA & $12 / 15$ & $3 / 15$ & $16(2.67-95.75)$ \\
Negi, 2012 [56] & Japan & Immunohistochemical methods & $149 / 196$ & $0 / 79$ & $500.43(30.44-8226.20)$ \\
Yamada, 2002 [57] & Japan & Quantitative real-time PCR for 16S rRNA & $8 / 9$ & $2 / 9$ & $28(2.07-379.25)$ \\
Eishi, 1994 [58] & Japan & PCR for P. acnes DNA & $36 / 39$ & $12 / 29$ & $17(4.23-68.28)$ \\
Abe, 1984 [19] & Japan & Isolation of P acnes in culture & $31 / 40$ & $38 / 180$ & $12.87(5.65-29.34)$ \\
Hiramatsu, 2003 [59] & Japan & Nested PCR for 16S rRNA & $21 / 30$ & $7 / 30$ & $7.67(2.42-24.24)$ \\
\hline 16S rDNA ris & &
\end{tabular}

16S rDNA ribosomal DNA, MALDI-IMS matrix-assisted laser desorption ionization as a mass spectrometry imaging, rRNA ribosomal RNA

second study did not reveal a significant association [3] (OR 0.43; CI:0-23.23), while in the third, all realtime PCR analyses for the detection of Rickettsia were negative [71]. None of the studies reported a significant association with Chlamydia pneumonia [7, 8, 72], Epstein-Barr virus [40], or retrovirus [73].

\section{Meta-analysis \\ Mycobacteria (Table 1)}

Both Mycobacterium tuberculosis complex (MTBC) and nontuberculous mycobacteria (NTM) were investigated in most of the 36 relevant studies, although some used primers to detect only $M$. tuberculosis [26, 28-33, 38, 39, 41, 42, 51, 52, 55], and others detected only nontuberculous mycobacteria $[44,50]$.

Figure 1 provides a forest plot for sarcoidosis and mycobacteria based on a total of 1034 sarcoidosis patients and 1054 controls. Of the 1034 sarcoidosis cases, 173 were positive for MTBC, and 58 were positive for NTM. It was not possible to identify the type of mycobacteria involved in 18 samples, while both types of mycobacteria DNA were present in one sample. In total, 250 sarcoidosis samples were positive for some form of mycobacteria DNA sequence for a positive signal rate of $24.2 \%$. We found a significant association between sarcoidosis and mycobacteria with an OR of 6.8 (95\% CI:3.73-12.39). A strong association was also found between sarcoidosis and NTM alone with an OR of 10.39 (95\% CI:5.25-20.56), as well as for M. tuberculosis complex (OR 4.29; CI:2.60-7.08). There was moderate heterogeneity among studies ( $\mathrm{I}^{2}$ test $52.1 \%$; $p=0.001)$, although all but three studies estimated a risk above unity with significance in most cases.

\section{P. acnes (Table 2)}

The risk of sarcoidosis associated with $P$. acnes was provided by the study design (Fig. 2). The OR derived from 11 studies with 534 cases and 488 controls was 18.80 (95\% CI:12.62-28.01), and there was low heterogeneity ( $\mathrm{I}^{2}$ test $25.9 \% ; p=0.206$ ). There was a positive signal rate of $68.54 \%$ for $P$. acnes (366 positive samples from 534

Table 3 Selected studies on the association between HHV-8 and sarcoidosis

\begin{tabular}{llllll}
\hline $\begin{array}{l}\text { First author/Year } \\
\text { (Ref.) }\end{array}$ & Country & Molecular technique & $\begin{array}{l}\text { Patients } \\
\mathrm{n} / \mathrm{N}\end{array}$ & $\begin{array}{l}\text { Controls } \\
\mathrm{n} / \mathrm{N}\end{array}$ & OR (95\% Cl) \\
\hline Knoell, 2005 [60] & USA & PCR for HHV-8 DNA & $0 / 8$ & $0 / 8$ & - \\
Gazouli, 2002 [22] & Greece & PCR for HHV-8 DNA & $0 / 46$ & $0 / 20$ & - \\
Fredricks, 2002 [61] & USA & PCR for HHV-8 ORF 26 DNA & $0 / 18$ & $0 / 4$ & - \\
Maeda, 2000 [62] & Japan & Hemi-nested PCR for HHV-8 DNA & $4 / 119$ & $4 / 120$ & $1.01(0.25-4.13)$ \\
Sugaya, 1999 [63] & Japan & Nested PCR for HHV-8 ORF 26 DNA & $0 / 12$ & $1 / 1$ & $0.01(0.00-0.95)$ \\
Bélec, 1998 [64] & France & Nested PCR for HHV-8 ORF 25/26 DNA & $0 / 14$ & $2 / 17$ & $0.21(0.01-4.84)$ \\
Di Alberti, 1997 [40] & Italy & Nested PCR for HHV-8 ORF 26 DNA & $38 / 39$ & $6 / 113$ & $677.67(79.01-5812.52)$ \\
& & and Heminested PCR for HHV-8 ORF 25 DNA & & & \\
\hline
\end{tabular}


Table 4 Selected studies on the association between Borrelia species and sarcoidosis

\begin{tabular}{|c|c|c|c|c|c|c|c|}
\hline \multirow{2}{*}{$\begin{array}{l}\text { First author/Year } \\
\text { (Ref.) }\end{array}$} & \multirow[t]{2}{*}{ Country } & \multirow[t]{2}{*}{ Molecular Technique } & \multicolumn{2}{|c|}{ Sarcoidosis } & \multicolumn{2}{|l|}{ Controls } & \multirow[t]{2}{*}{ OR $(95 \% \mathrm{Cl})$} \\
\hline & & & $n / N$ & Type of microorganism & $n / N$ & Type of microorganism & \\
\hline Derler, 2009 [4] & Austria & $\begin{array}{l}\text { Focus-floating microscopy } \\
\text { and Borrelia-specific PCR DNA }\end{array}$ & $13 / 35$ & Borrelia sp. & $1 / 61$ & Borrelia sp. & $35.45(4.38-287.16)$ \\
\hline Ishihara, 1998 [65] & Japan & $\begin{array}{l}\text { Dot-blot analysis } \\
\text { (Dotblot Borrelia Kit) }\end{array}$ & $15 / 46$ & Borrelia sp. & $2 / 100$ & Borrelia sp. & $23.71(5.14-109.46)$ \\
\hline Martens, 1997 [66] & Germany & $\begin{array}{l}\text { Western blot for } \\
\text { Borrelia burgdorferi }\end{array}$ & $1 / 60$ & Borrelia burgdorferi & $27 / 1000$ & Borrelia burdorferi & $0.61(0.08-4.57)$ \\
\hline Lian, 1995 [67] & China & $\begin{array}{l}\text { PCR for Borrelia } \\
\text { burgdorferi DNA }\end{array}$ & $6 / 49$ & Borrelia burgdorferi & $2 / 28$ & Borrelia burgdorferi & $1.81(0.34-9.66)$ \\
\hline Xu, 1996 [68] & China & $\begin{array}{l}\text { In situ PCR for } \\
\text { Borrelia burgdorferi DNA }\end{array}$ & $0 / 23$ & - & $0 / 23$ & - & - \\
\hline Ishihara, 1996 [69] & Japan & $\begin{array}{l}\text { Elisa and Dot-blot } \\
\text { analysis for Borrelia sp. }\end{array}$ & $1 / 38$ & Borrelia sp. & $1 / 80$ & Borrelia sp. & $2.14(0.13-35.08)$ \\
\hline
\end{tabular}

patients). When accounting for the source of biological samples studied, we found that nine of the 11 studies $[19,22,24,25,35,38,56-58]$ evaluated the presence of $P$. acnes in lymph node samples, of which seven evaluated this location exclusively $[19,24,35,38,57$, 58]. This could justify the low heterogeneity among studies, contrary to what was observed in the forest plot of mycobacteria, where the studied biological samples were more heterogeneous.

\section{Borrelia and HHV-8 (Tables 3 and 4)}

Of the six articles assessing the presence of Borrelia in sarcoidosis tissues, three used polymerase chain reaction (PCR) techniques for DNA amplification of B. burgdorferi

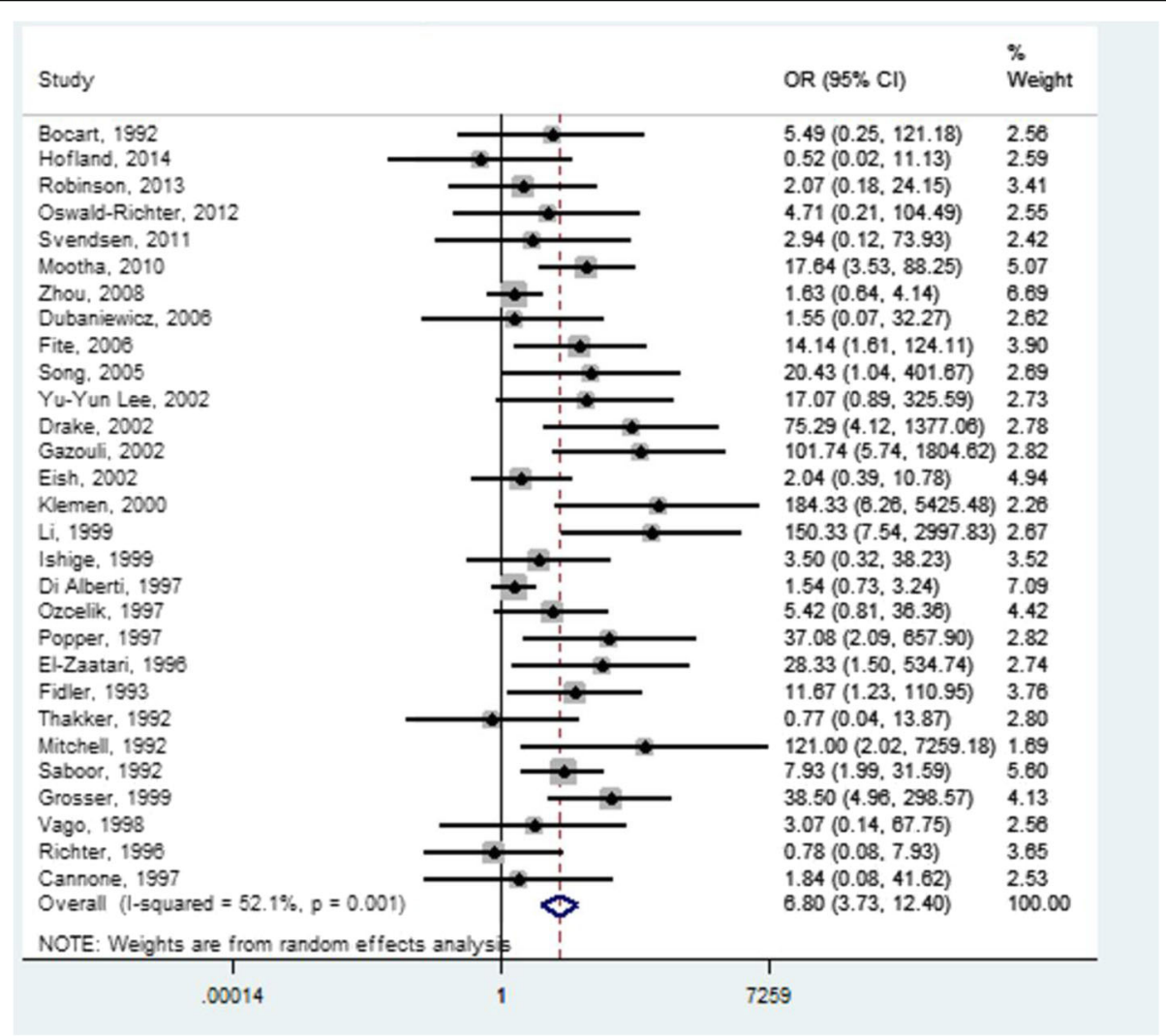

Fig. 1 Forest plot of studies that show the presence of mycobacteria in sarcoidosis patients versus controls 


\begin{tabular}{|l|lll} 
& & & \multicolumn{2}{c}{$\%$} \\
Weight
\end{tabular}

Fig. 2 Forest plot of studies that show the presence of $P$. acnes in sarcoidosis patients versus controls

[66-68], whereas the other three did not specify which species of Borrelia were involved [4,65,69]. The pooled OR derived from these six studies with 251 cases and 1292 controls was 4.82, but this result did not reach statistical significance (95\% CI:0.98-23.81). Statistical heterogeneity was moderate with an $\mathrm{I}^{2}$ of $70 \%$ and $p=0.01$ Fig. 3 a).

Di Alberti et al [40] were the only ones to report a significant association between sarcoidosis and HHV-8 in comparison with controls. However, the remaining six studies refuted those results [22, 6064]. Overall, there was no significant association between sarcoidosis and HHV-8 (OR 1.47; CI:0.02110.06), and there was high heterogeneity among studies ( $\mathrm{I}^{2}$ test $92 \%$; $p=0.000$ ) (Fig. $3 \mathrm{~b}$ ).

\section{Evaluation of publication bias}

We performed funnel plots to evaluate publication bias (Fig. 4). The funnel plots of HHV-8 and mycobacteria showed evidence of publication bias (Fig. 4b and c), while the graphs regarding the presence of Borrelia and $P$. acnes are fairly symmetrical (Fig. $4 \mathrm{a}$ and $\mathrm{d}$ ). Thus, no suggestion of publication bias is indicated in these cases.

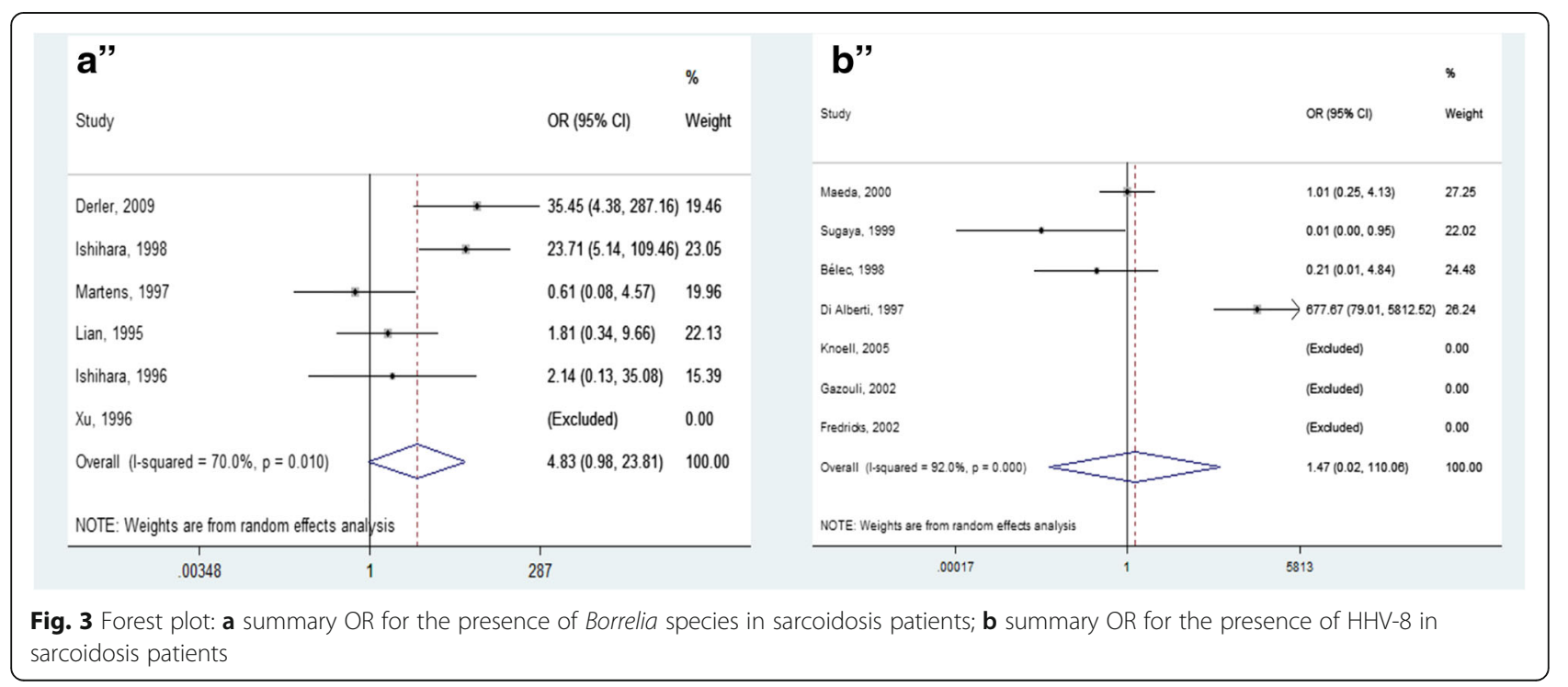




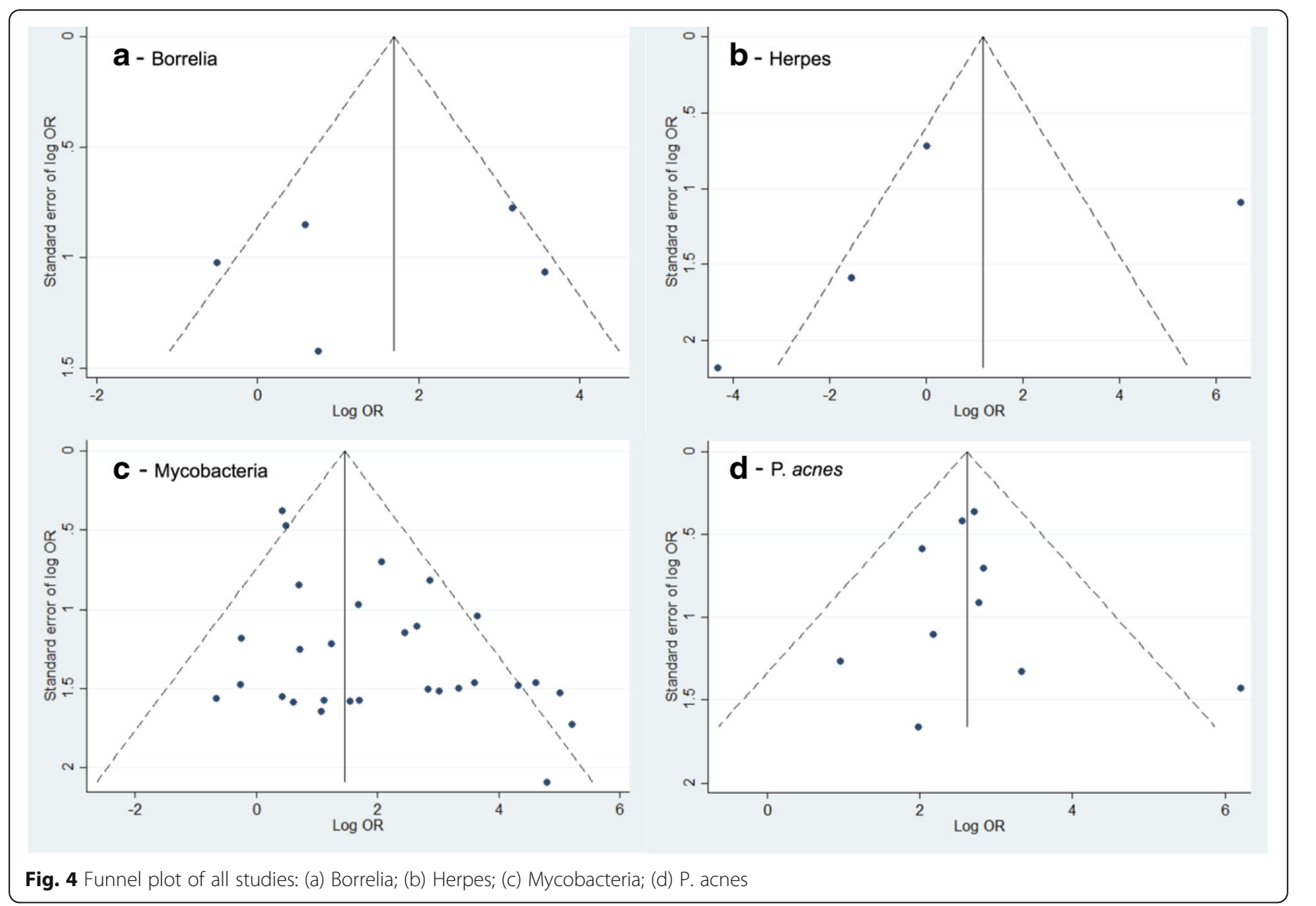

\section{Sensitivity and subgroup analysis}

To verify the robustness of the results, as well as the potential sources of heterogeneity, subgroup and sensitivity analyses were performed (especially for mycobacteria).

\section{Subgroup analysis}

Concerning the studies of mycobacteria, we conducted subgroup meta-analysis by various study characteristics (Table 5). The pooled OR was calculated in subgroups of studies according to geographical area, publication year, type of study, and molecular technique used. There was a significant association between sarcoidosis and mycobacteria in all subgroups, except in three studies included in the subgroup of molecular techniques (BD ProbeTec and culture). The pooled OR was significantly higher with some covariates, however almost all of the ORs derived from these subgroup data were significantly above unity.

Through the subgroup analyses, it was noted that the variables that most influenced the results of heterogeneity were: a) the study type, being null the heterogeneity in the ten prospective studies, contrasting with the moderate heterogeneity in retrospective studies; b) the geographical location, verifying a low heterogeneity in studies conducted in the USA and Asia.

\section{Sensitivity analysis}

We also performed a sensitivity analysis to complement the subgroup analysis in order to better explain the heterogeneity between studies (Table 5).

Regarding sarcoidosis and mycobacteria, there was a strong and significant association (OR 4.33; CI:2.069.10) in subgroup analysis of geographic locations when we restricted to studies performed in countries with low burden of tuberculosis [24, 30, 35, 38, 40, 42, 44-46, 49, $51,53]$. There was low heterogeneity among these studies $\left(\mathrm{I}^{2}\right.$ test $45.7 \% ; p=0.042$ ) (Table 5 ).

Another subgroup analysis compared the results according to the different biological samples used. Most of the studies included in our meta-analysis used biological samples from different locations, including the skin, lymph nodes, and lungs. However, when we restricted the analysis to include only studies that performed PCR on biological samples of the same type, the associations were also significant in both lung samples [30, 40, 45] (OR 2.93; CI:1.09-7.86; $\mathrm{I}^{2}=56.9 \%$ ) and lymph node samples [24, 35, 38, 40, 46] (OR 3.82; CI:1.53-9.49; $\mathrm{I}^{2}=$ 
Table 5 Subgroup and sensitivity analysis of the association between sarcoidosis and mycobacteria

\begin{tabular}{|c|c|c|c|c|}
\hline & No. of studies & OR $(95 \% \mathrm{Cl})$ & $P$-value heterogeneity & $P^{2}(\%)$ \\
\hline \multicolumn{5}{|l|}{ Subgroup analysis } \\
\hline \multicolumn{5}{|l|}{1 - Geographical region } \\
\hline Europe & 22 & $6.92(3.05,15.71)$ & 0.004 & 53.8 \\
\hline USA & 7 & $18.21(4.64,71.53)$ & 0.238 & 26.2 \\
\hline Asia & 7 & $4.09(1.38,12.12)$ & 0.093 & 49.8 \\
\hline \multicolumn{5}{|l|}{2 - Publication year } \\
\hline$<2000$ & 20 & $6.63(2.84,15.51)$ & 0.006 & 54.2 \\
\hline$>=2000$ & 16 & $8.40(3.31,21.31)$ & 0.012 & 53 \\
\hline \multicolumn{5}{|l|}{3 - Type of study } \\
\hline Prospective & 10 & $11.91(4.94,28.69)$ & 0.743 & 0.0 \\
\hline Retrospective & 26 & $6.41(3.14,13.09)$ & 0.001 & 57.1 \\
\hline \multicolumn{5}{|l|}{4 - Molecular technique } \\
\hline$P C R$ & 29 & $7.04(3.57,13.89)$ & 0.000 & 58.8 \\
\hline Hybridization & 2 & $37.81(3.40,420.43)$ & 0.484 & 0.0 \\
\hline Protein analysis & 2 & $12.12(1.44,102.20)$ & 0.408 & 0.0 \\
\hline BD ProbeTec & 2 & $2.09(0.23,19.10)$ & 0.776 & 0.0 \\
\hline Culture & 1 & $0.52(0.02,11.13)$ & - & - \\
\hline \multicolumn{5}{|l|}{ Sensitivity analysis } \\
\hline \multicolumn{5}{|l|}{1 - Biological samples } \\
\hline Only lymph nodes & 11 & $3.82(1.53,9.49)$ & 0.384 & 4.0 \\
\hline Only lung & 5 & $2.93(1.09,7.86)$ & 0.098 & 56.9 \\
\hline Only skin & 2 & $11.58(0.06,2016.91)$ & 0.021 & 81.3 \\
\hline \multicolumn{5}{|l|}{2 - Incidence of tuberculosis } \\
\hline Only countries with low burden of TB & 33 & $4.33(2.06,9.10)$ & 0.042 & 45.7 \\
\hline
\end{tabular}

$4 \%)$, but not skin biological specimens [37, 40] (OR 11.58; CI:0.06-2016.91; $\left.\mathrm{I}^{2}=81.3 \%\right)$. Once again, the heterogeneity among studies was low to moderate except in two studies performed on skin biopsies (Table 5).

In sensitivity analysis on studies of sarcoidosis and $P$. acnes, we found a significant association compared with the controls when we selected only studies performed outside Asia [22, 24, 25], with a pooled OR of 5.5 (95\% CI:1.13-27.42) and no heterogeneity among studies.

\section{Discussion}

The present meta-analysis is the first to evaluate all infectious agents proposed to be associated with sarcoidosis and involving more than 6000 patients in several countries. The results point to an etiological link between $P$. acnes and sarcoidosis with a positive signal rate of $68.54 \%$. Also, almost one quarter of sarcoidosis patients show the presence of mycobacteria within the lesions. The associations are fairly specific, since $P$. acnes (OR 18.80) and mycobacteria (OR 6.8) were significantly increased in sarcoidosis patients, while Borrelia (OR 4.82; CI:0.98-23.81) and HHV-8 (OR 1.47; CI:0.02-
110.06) were not associated with sarcoidosis, contrary to previous investigations.

Three decades ago, Abe et al [19] reported that $P$. acnes was the only bacterium isolated in lymph node biopsy samples taken from sarcoidosis patients. Studies published in recent years have confirmed that $P$. acnes could be a possible infectious agent implicated in the pathogenesis of sarcoidosis [24, 56, 74-76]. However, some studies suggest that $P$. acnes is not specific for sarcoidosis because it is a normal inhabitant of peripheral lung tissue and mediastinal lymph nodes, apart from the skin [77]. Despite this, the results of our meta-analysis show a significant quantitative difference in the presence of the $P$. acnes genome in sarcoidosis patients compared to control subjects. This suggests that this microorganism may be present abnormally or may proliferate ectopically in such sarcoid lesions.

However, it is important to note that most of the studies in our meta-analysis evaluating the role of $P$. acnes in sarcoidosis were by Japanese groups testing Japanese patients, while only very limited data exist for African American or Caucasian patients [22, 24, 25]. The results 
were conflicting in these three studies, but interestingly, the pooled OR was above unity and statistically significant (5.58; CI:1.13-27.42). Despite these surprising results, the ORs observed in studies with Japanese patients were far superior, and the results were more consistent and robust. Differences between these two groups may be due to the geographical, ethnic, or racial composition of the study population. Sarcoidosis in Japanese patients is characterized by a high rate of ocular, cutaneous, and cardiac involvement, while in Europe and the USA, this disease mainly affects the lungs.

In 2002, the first large, relevant study was published as a collaboration between several countries [35]. The results of this international study suggest an association between $P$. acnes and sarcoidosis in not only Japanese patients (positive signal rate of $89.2 \%$ ), but also in Europeans (positive signal rate of $81.4 \%$ ). However, more international corporative studies with quantitative PCR are needed to clarify the role of $P$. acnes in sarcoidosis and for better understanding of the phenotypic variability of this disease.

Recent years have witnessed substantial discussion among investigators about the role that mycobacteria may have in the pathogenesis of sarcoidosis, and the issue remains unsettled, if not controversial. With the emergence of new microbiological techniques, especially in the molecular biology area, several studies have been conducted in order to investigate this possible association more deeply.

In the present meta-analysis, we identified 36 studies assessing the presence of mycobacteria in a total of 1034 sarcoidosis patients and 1054 controls. The results suggest a strong association of sarcoidosis with NTM (OR 10.39; CI:5.25-20.56) and with MTBC (4.29; CI:2.607.08). However, to evaluate the possible relationship between mycobacteria and sarcoidosis, the current incidence of tuberculosis should be taken into account in general populations of the different countries where the studies of sarcoidosis were performed. In the sensitivity analyses, a significant association was also found (OR 4.33; CI:2.06-9.10) when we restricted the analysis to include only studies performed in countries with low prevalence of tuberculosis. This further confirms the robustness of the results and the relevance of this association worldwide.

Despite the heterogeneity of analyzed studies and the potential publication bias suggested by the mycobacteria funnel plots, most of the ORs derived from individual data were significantly above unity. Furthermore, sensitivity and subgroup analyses including only studies performed on lung samples or lymph nodes showed low heterogeneity. Therefore, it is important to account for the heterogeneity in sarcoidosis specimens (lung versus skin or lymph nodes). We found significant increased
ORs in studies performed on lung or lymph node samples but not in skin specimens. Possible explanations for this include the following: 1) In the initial phase of the disease, systemic sarcoidosis primarily affects and spreads through the lymphatic system, following the lymphatic vessels to the hilar and mediastinal lymph nodes. 2) Lung and lymph node samples are obtained sterilely by endoscopy biopsies and thus avoid possible microorganism contamination, in contrast to skin biopsies. 3) The two studies performed on sarcoidosis skin samples were both retrospective [37, 40]. In such studies, there is a greater possibility of both contamination of the paraffin-embedded specimens and more DNA fragmentation. In contrast, several studies performed on lung and lymph node samples were prospective, and only fresh tissues were used. Additionally, when we conducted the subgroup analysis according to the type of study, it was found a low heterogeneity in the 10 prospective studies $\left(\mathrm{I}^{2}=0 \%\right)$, contrasting with the moderate heterogeneity in retrospective studies $\left(\mathrm{I}^{2}=57.1 \%\right)$.

The hypothesis that $B$. burgdorferi could be a possible causal infectious agent for sarcoidosis was first mentioned in 1989 in epidemiological studies [78]. Since then, several studies have been conducted using serological or molecular techniques in order to clarify the role of Borrelia in the pathogenesis of sarcoidosis. We identified six articles assessing the presence of Borrelia in sarcoidosis tissues using molecular techniques (251 cases and 1292 controls), and we did not find a significant association (OR 4.82; CI:0.98-23.81). On the other hand, the two studies that reported a significant association between Borrelia and sarcoidosis $[4,65]$ were both conducted in regions where Lyme disease is endemic, in contrast to the four other articles performed in nonendemic areas [66-69], where the results did not reach statistical significance.

It is important to note that the frequency of exposure to Borrelia. spirochete is different between patients living in regions where the disease is endemic and those in regions where it is not. Thus, in countries with elevated $B$. burgdorferi prevalence, a protective immunity against this microorganism has to be assumed in the general population. T-helper lymphocyte activity to this microorganism might be a trigger for the development of sarcoidosis in endemic regions, which could explain the positive results in studies published in Austria and Japan $[4,65]$. Apart from these two studies, the fact that significant positive PCR results could not be found argues against the hypothesis of a connection between B. burgdorferi infection and sarcoidosis. However, more studies are needed to clarify the possible association, especially in endemic areas.

There are several clinical implications of this study. Currently, immune suppression remains the primary 
treatment modality for sarcoidosis. Given our metaanalysis, it is worth exploring whether certain antibacterial or antimycobacterial drugs might alter the course of sarcoidosis. In the past, some clinical trials have been published with conflicting results using classical antituberculous drugs, such as isoniazid, amino-salicylic acid, and streptomycin [79-82]. Recently, Drake et al [83] conducted a double-blind, placebo-controlled study to investigate the efficacy of oral antimycobacterial therapy (levofloxacin, ethambutol, azithromycin, and rifampin) in patients with cutaneous sarcoidosis. The results were promising, with significant reductions in cutaneous lesion size. The same authors also conducted an open-label investigation using the same therapy regimen in pulmonary sarcoidosis patients, and the results were again very interesting with significant improvements in forced vital capacity from baseline to completion of therapy [84].

Other antimicrobial agents such as minocycline and doxycycline have been shown to be quite effective in treating cutaneous sarcoidosis in some series $[85,86]$. However, the exact mechanism of action of these drugs it is not fully understood [87].

Currently, other clinical trials are being done (NCT02024555 and NCT01245036) to clarify the role that antimicrobial agents might have in the treatment of sarcoidosis.

Several limitations in our study should be recognized. First, one of the main potential limitations relates to the variability and heterogeneity of the results analyzed. It is important to consider that the majority of these studies were assessed retrospectively and that data were obtained from different databases and hospitals. This could lead to different types of bias in the included studies and to variability in the results. Second, the risk of contamination or DNA fragmentation in PCR techniques can lead to false positive or false negative results. In addition, PCR does not discriminate between living and dead microorganisms. Third, the patients had varied clinical manifestations of sarcoidosis; moreover, the non-sarcoidosis controls were comprised of different types of subjects across the studies, which may cause misclassification bias and heterogeneity.

\section{Conclusion}

The present meta-analysis, involving more than 6000 patients from various countries worldwide, suggests a significant association between sarcoidosis and some infectious agents, taking into account the marked difference in the percentage of microbial DNA-positive samples in sarcoidosis patients versus controls, especially mycobacteria (OR 6.8) and P. acnes (OR 18.80). Furthermore, our study also suggests caution regarding a putative association between sarcoidosis and B. burgdorferi.

What seems clear is that more than one infectious agent might be implicated in the pathogenesis of sarcoidosis; probably the patient's geographical location might dictate which microorganisms are more involved.

More studies and clinical trials are needed to extend this evidence to a more global level.

\section{Additional files}

Additional file 1: PRISMA Checklist (PDF $545 \mathrm{~kb}$ )

Additional file 2: Search strategy of MEDLINE via OVID. (DOC $22 \mathrm{~kb}$ )

Additional file 3: Flow diagram of the current meta-analysis.

(DOC 1550 kb)

\section{Abbreviations}

B. burgdorferi: Borrelia burgdorferi; Cl: Confidence interval; HHV-8: Human herpesvirus 8; MTBC: Mycobacterium tuberculosis complex;

NTM: Nontuberculous mycobacteria; OR: Odds ratio; $P$.

acnes: Propionibacterium acnes; PRISMA: Preferred Reporting Items for

Systematic Reviews and Meta-Analyses

\section{Acknowledgements}

We thank Miguel Angel Descalzo, responsible for the research unit of the Spanish Academy of Dermatology and Venereology (AEDV), for his assistance with statistical analysis and Rubina Alves, M.D., for reviewing an earlier version of the manuscript.

Funding

None.

Availability of data and materials

We declare that the data supporting the conclusions of this article are fully described in the article.

\section{Authors' contribution}

TE and VGP contributed equally to the study. TE, GA and VGP conceived the study and designed the systematic review and meta-analysis. TE, GA and VGP contributed to the data extraction, performed the analysis and interpreted the results. TE and VGP wrote the first draft; TE, GA and VGP contributed to the revision of the final report. All authors read and approved the final manuscript.

\section{Competing interests}

The authors declare that they have no competing interests.

Consent for publication

Not applicable.

\section{Ethics approval and consent to participate}

Since this study was a literature review and meta-analysis of previously reported studies, ethical approval or additional consent from participants was not required.

\section{Prior presentation}

This data has not been published elsewhere.

\section{Author details}

${ }^{1}$ Department of Medicine, Universitat Autònoma de Barcelona, Passeig de la Vall d'Hebron, 119-129, 08035 Barcelona, Spain. ²Department of Dermatology, Hospital Universitari Vall d'Hebron, Barcelona, Spain.

Received: 17 May 2016 Accepted: 22 November 2016

Published online: 28 November 2016

\section{References}

1. Haimovic A, Sanchez M, Judson MA, Prystowsky S. Sarcoidosis: a comprehensive review and update for the dermatologist: part I. Cutaneous disease. J Am Acad Dermatol. 2012;66(5):699-718.

2. Newman LS, Rose CS, Bresnitz EA, Rossman MD, Barnard J, Frederick M, Terrin ML, Weinberger SE, Moller DR, McLennan G, Hunninghake G, DePalo 
L, Baughman RP, lannuzzi MC, Judson MA, Knatterud GL, Thompson BW Teirstein AS, Yeager Jr H, Johns CJ, Rabin DL, Rybicki BA, Cherniack R, ACCESS Research Group. A case control etiologic study of sarcoidosis: environmental and occupational risk factors. Am J Respir Crit Care Med. 2004;170(12):1324-30.

3. Svendsen CB, Milman N, Nielsen HW, Krogfelt KA, Larsen KR. A prospective study evaluating the presence of Rickettsia in Danish patients with sarcoidosis. Scand J Infect Dis. 2009;41(10):745-52.

4. Derler AM, Eisendle K, Baltaci M, Obermoser G, Zelger B. High prevalence of 'Borrelia-like' organisms in skin biopsies of sarcoidosis patients from Western Austria. J Cutan Pathol. 2009;36(12):1262-8.

5. Planck A, Eklund A, Grunewald J, Vene S. No serological evidence of Rickettsia Helvetica infection in Scandinavian sarcoidosis patients. Eur Respir J. 2004;24(5):811-3.

6. Lebbé C, Agbalika F, Flageul B, Pellet C, Rybojad M, Cordoliani F, Farge D, Vignon-Pennamen MD, Sheldon J, Morel P, Calvo F, Schulz TF. No evidence for a role of human herpesvirus type 8 in sarcoidosis: molecular and serological analysis. Br J Dermatol. 1999;141(3):492-6.

7. Mills GD, Allen RK, Timms P. Chlamydia pneumoniae DNA is not detectable within sarcoidosis tissue. Pathology. 1998;30(3):295-8.

8. Blasi F, Rizzato G, Gambacorta M, Cosentini R, Raccanelli R, Tarsia P, Arosio C, Savini E, Cantoni C, Fagetti L, Allegra L. Failure to detect the presence of Chlamydia pneumoniae in sarcoid pathology specimens. Eur Respir J. 1997; 10(11):2609-11.

9. Biberfeld $P$, Petrén AL, Eklund $A$, Lindemalm C, Barkhem T, Ekman $M$, Ablashi D, Salahuddin Z. Human herpesvirus-6 (HHV-6, HBLV) in sarcoidosis and lymphoproliferative disorders. J Virol Methods. 1988;21(1-4):49-59.

10. Moravvej H, Vesal P, Abolhasani E, Nahidi S, Mahboudi F. Comorbidity of leishmania major with cutaneous sarcoidosis. Indian J Dermatol. 2014;59(3):316

11. Suchankova M, Paulovicova E, Paulovicova L, Majer I, Tedlova E, Novosadova H, Tibenska E, Tedla M, Bucova M. Increased antifungal antibodies in bronchoalveolar lavage fluid and serum in pulmonary sarcoidosis. Scand J Immunol. 2015;81(4):259-64.

12. Gupta D, Agarwal R, Aggarwal AN, Jindal SK. Molecular evidence for the role of mycobacteria in sarcoidosis: a meta-analysis. Eur Respir J. 2007;30(3):508-16.

13. Zhou Y, Hu Y, Li H. Role of Propionibacterium Acnes in Sarcoidosis: A Metaanalysis. Sarcoidosis Vasc Diffuse Lung Dis. 2013;30(4):262-7.

14. Iannuzzi MC, Rybicki BA, Teirstein AS. Sarcoidosis. N Engl J Med. 2007; 357(21):2153-65

15. DerSimonian R, Laird N. Meta-analysis in clinical trials. Control Clin Trials. 1986;7(3):177-88

16. Greenland S. Variance estimators for attributable fraction estimates consistent in both large strata and sparse data. Stat Med. 1987;6(6):701-8.

17. Higgins JP, Thompson SG, Deeks JJ, Altman DG. Measuring inconsistency in meta-analyses. BMJ. 2003;327(7414):557-60.

18. Mantel $\mathrm{N}$, Haenszel W. Statistical aspects of the analysis of data from retrospective studies of disease. J Natl Cancer Inst. 1959;22(4):719-48.

19. Abe C, Iwai K, Mikami R, Hosoda Y. Frequent isolation of Propionibacterium acnes from sarcoidosis lymph nodes. Zentralbl Bakteriol Mikrobiol Hyg A. 1984;256(4):541-7.

20. Hofland RW, Thijsen SF, Bouwman J, van der Wel M, Bossink AW. Sarcoidosis and Purified Protein Derivative reactivity. Sarcoidosis Vasc Diffuse Lung Dis. 2014;31(2):142-8.

21. Drake WP, Pei Z, Pride DT, Collins RD, Cover TL, Blaser MJ. Molecular analysis of sarcoidosis tissues for mycobacterium species DNA. Emerg Infect Dis. 2002;8(11):1334-41.

22. Gazouli M, Ikonomopoulos J, Trigidou R, Foteinou M, Kittas C, Gorgoulis V. Assessment of mycobacterial, propionibacterial, and human herpesvirus 8 DNA in tissues of Greek patients with sarcoidosis. J Clin Microbiol. 2002; 40(8):3060-3.

23. Bocart D, Lecossier D, De Lassence A, Valeyre D, Battesti JP, Hance AJ. A search for mycobacterial DNA in granulomatous tissues from patients with sarcoidosis using the polymerase chain reaction. Am Rev Respir Dis. 1992; 145(5):1142-8

24. Robinson LA, Smith P, Sengupta DJ, Prentice JL, Sandin RL. Molecular analysis of sarcoidosis lymph nodes for microorganisms: a case-control study with clinical correlates. BMJ Open. 2013;3(12):e004065.

25. Oswald-Richter KA, Beachboard DC, Seeley EH, Abraham S, Shepherd BE, Jenkins CA, Culver DA, Caprioli RM, Drake WP. Dual analysis for mycobacteria and propionibacteria in sarcoidosis BAL. J Clin Immunol. 2012; 32(5):1129-40.
26. Svendsen CB, Milman N, Rasmussen EM, Thomsen VØ, Andersen CB, Krogfelt KA. The continuing search for Mycobacterium tuberculosis involvement in sarcoidosis: a study on archival biopsy specimens. Clin Respir J. 2011:5(2):99-104.

27. Mootha VK, Agarwal R, Aggarwal AN, Gupta D, Ahmed J, Verma I, Bal A. The Sarcoid-Tuberculosis link: evidence from a high TB prevalence country. J Infect. 2010;60(6):501-3.

28. Zhou Y, Li HP, Li QH, Zheng H, Zhang RX, Chen G, Baughman RP. Differentiation of sarcoidosis from tuberculosis using real-time PCR assay for the detection and quantification of Mycobacterium tuberculosis. Sarcoidosis Vasc Diffuse Lung Dis. 2008;25(2):93-9.

29. Dubaniewicz A, Dubaniewicz-Wybieralska M, Sternau A, Zwolska Z, IzyckaSwieszewska E, Augustynowicz-Kopec E, Skokowski J, Singh M, Zimnoch L. Mycobacterium tuberculosis complex and mycobacterial heat shock proteins in lymph node tissue from patients with pulmonary sarcoidosis. J Clin Microbiol. 2006;44(9):3448-51.

30. Fité E, Fernández-Fiqueras MT, Prats R, Vaquero M, Morera J. High prevalence of Mycobacterium tuberculosis DNA in biopsies from sarcoidosis patients from Catalonia, Spain. Respiration. 2006;73(1):20-6.

31. Yasuhara T, Tada R, Nakano Y, Tei M, Mochida C, Kamei M, Kinoshita S. The presence of Propionibacterium spp. in the vitreous fluid of uveitis patients with sarcoidosis. Acta Ophthalmol Scand. 2005;83(3):364-9.

32. Song Z, Marzilli L, Greenlee BM, Chen ES, Silver RF, Askin FB, Teirstein AS, Zhang Y, Cotter RJ, Moller DR. Mycobacterial catalase-peroxidase is a tissue antigen and target of the adaptive immune response in systemic sarcoidosis. J Exp Med. 2005;201(5):755-67.

33. Marcoval J, Benítez MA, Alcaide F, Mañá J. Absence of ribosomal RNA of Mycobacterium tuberculosis complex in sarcoidosis. Arch Dermatol. 2005; 141(1):57-9.

34. Lee JY, Chao SC, Yang MH, Yan JJ. Sarcoidosis in Taiwan: clinical characteristics and atypical mycobacteria. J Formos Med Assoc. 2002; 101(11):749-55.

35. Eishi Y, Suga M, Ishige I, Kobayashi D, Yamada T, Takemura T, Takizawa T, Koike M, Kudoh S, Costabel U, Guzman J, Rizzato G, Gambacorta M, du Bois R, Nicholson AG, Sharma OP, Ando M. Quantitative analysis of mycobacterial and propionibacterial DNA in lymph nodes of Japanese and European patients with sarcoidosis. J Clin Microbiol. 2002;40(1):198-204.

36. Klemen H, Husain AN, Cagle PT, Garrity ER, Popper HH. Mycobacterial DNA in recurrent sarcoidosis in the transplanted lung-a PCR-based study on four cases. Virchows Arch. 2000;436(4):365-9.

37. Li N, Bajoghli A, Kubba A, Bhawan J. Identification of mycobacterial DNA in cutaneous lesions of sarcoidosis. J Cutan Pathol. 1999;26(6):271-8.

38. Ishige I, Usui Y, Takemura T, Eishi Y. Quantitative PCR of mycobacterial and propionibacterial DNA in lymph nodes of Japanese patients with sarcoidosis. Lancet. 1999;354(9173):120-3.

39. Wilsher ML, Menzies RE, Croxson MC. Mycobacterium tuberculosis DNA in tissues affected by sarcoidosis. Thorax. 1998;53(10):871-4.

40. Di Alberti L, Piattelli A, Artese L, Favia G, Patel S, Saunders N, Porter SR, Scully CM, Ngui SL, Teo CG. Human herpesvirus 8 variants in sarcoid tissues. Lancet. 1997;350(9092):1655-61.

41. Vokurka M, Lecossier D, du Bois RM, Wallaert B, Kambouchner M, Tazi A, Hance AJ. Absence of DNA from mycobacteria of the M. tuberculosis complex in sarcoidosis. Am J Respir Crit Care Med. 1997;156(3 Pt 1):1000-3.

42. Ozçelik U, Ozkara HA, Göçmen A, Akçören Z, Kocagöz T, Kiper N, Göğüs S, Cağlar M, Kale G, Kotiloğlu E. Detection of Mycobacterium tuberculosis DNA in tissue samples of children with sarcoidosis. Pediatr Pulmonol. 1997;24(2): $122-4$.

43. Popper $\mathrm{HH}$, Klemen $\mathrm{H}$, Hoefler $\mathrm{G}$, Winter E. Presence of mycobacterial DNA in sarcoidosis. Hum Pathol. 1997;28(7):796-800.

44. el-Zaatari FA, Naser SA, Markesich DC, Kalter DC, Engstand L, Graham DY. Identification of Mycobacterium avium complex in sarcoidosis. I Clin Microbiol. 1996;34(9):2240-5.

45. Fidler HM, Rook GA, Johnson NM, McFadden J. Mycobacterium tuberculosis DNA in tissue affected by sarcoidosis. BMJ. 1993;306(6877):546-9.

46. Thakker B, Black M, Foulis AK. Mycobacterial nucleic acids in sarcoid lesions. Lancet. 1992;339(8808):1537.

47. Gerdes J, Richter E, Rüsch-Gerdes S, Greinert V, Galle J, Schlaak M, Flad HD, Magnussen H. Mycobacterial nucleic acids in sarcoid lesions. Lancet. 1992; 339(8808):1536-7.

48. Mitchell IC, Turk JL, Mitchell DN. Detection of mycobacterial rRNA in sarcoidosis with liquid-phase hybridisation. Lancet. 1992;339(8800):1015-7. 
49. Saboor SA, Johnson NM, McFadden J. Detection of mycobacterial DNA in sarcoidosis and tuberculosis with polymerase chain reaction. Lancet. 1992; 339(8800):1012-5.

50. Lisby G, Milman N, Jacobsen GK. Search for Mycobacterium paratuberculosis DNA in tissue from patients with sarcoidosis by enzymatic gene amplification. APMIS. 1993;101(11):876-8.

51. Grosser M, Luther T, Müller J, Schuppler M, Bickhardt J, Matthiessen W, Müller M. Detection of M. tuberculosis DNA in sarcoidosis: correlation with T-cell response. Lab Invest. 1999;79(7):775-84.

52. Vago L, Barberis M, Gori A, Scarpellini P, Sala E, Nebuloni M, Bonetto S, Cannone M, Marchetti G, Franzetti F, Costanzi G. Nested polymerase chain reaction for Mycobacterium tuberculosis IS6110 sequence on formalin-fixed paraffin-embedded tissues with granulomatous diseases for rapid diagnosis of tuberculosis. Am J Clin Pathol. 1998;109(4):411-5.

53. Richter E, Greinert U, Kirsten D, Rüsch-Gerdes S, Schlüter C, Duchrow M, Galle J, Magnussen H, Schlaak M, Flad HD, Gerdes J. Assessment of mycobacterial DNA in cells and tissues of mycobacterial and sarcoid lesions. Am J Respir Crit Care Med. 1996;153(1):375-80.

54. Ghossein RA, Ross DG, Salomon RN, Rabson AR. A search for mycobacteria DNA in sarcoidosis using the polymerase chain reaction. Am J Clin Pathol. 1994:101(6):733-7.

55. Cannone M, Vago L, Porini G, Bonetto S, Cassi C, Bramerio M, Rizzato G, Barberis MC. Detection of mycobacterium tuberculosis DNA using nested polymerase chain reaction in lymph nodes with sarcoidosis, fixed in formalin and embedded in paraffin. Pathologica. 1997;89(5):512-6.

56. Negi M, Takemura T, Guzman J, Uchida K, Furukawa A, Suzuki Y, lida T, Ishige I, Minami J, Yamada T, Kawachi H, Costabel U, Eishi Y. Localization of Propionibacterium acnes in granulomas supports a possible etiologic link between sarcoidosis and the bacterium. Mod Pathol. 2012;25(9):1284-97.

57. Yamada T, Eishi Y, Ikeda S, Ishige I, Suzuki T, Takemura T, Takizawa T, Koike M. In situ localization of Propionibacterium acnes DNA in lymph nodes from sarcoidosis patients by signal amplification with catalysed reporter deposition. J Pathol. 2002;198(4):541-7.

58. Eishi Y. Seeking a causative agent of sarcoidosis. Nihon Rinsho. 1994;52(6):1486-91.

59. Hiramatsu J, Kataoka M, Nakata Y, Okazaki K, Tada S, Tanimoto M, Eishi Y. Propionibacterium acnes DNA detected in bronchoalveolar lavage cells from patients with sarcoidosis. Sarcoidosis Vasc Diffuse Lung Dis. 2003;20(3): 197-203.

60. Knoell KA, Hendrix Jr JD, Stoler MH, Patterson JW, Montes CM. Absence of human herpesvirus 8 in sarcoidosis and crohn disease granulomas. Arch Dermatol. 2005;141(7):909-10.

61. Fredricks DN, Martin TM, Edwards AO, Rosenbaum JT, Relman DA. Human herpesvirus 8 and sarcoidosis. Clin Infect Dis. 2002;34(4):559-60.

62. Maeda H, Niimi T, Sato S, Kawaguchi H, Sugiura Y, Mori S, Ueda R. Human herpesvirus 8 is not associated with sarcoidosis in Japanese patients. Chest. 2000;118(4):923-7.

63. Sugaya M, Nakamura K, Takahiro W, Tamaki K. Human herpesvirus type 8 is not detected in cutaneous lesions of sarcoidosis. Br J Dermatol. 1999;141(4):769.

64. Bélec L, Mohamed AS, Lechapt-Zalcman E, Authier FJ, Lange F, Gherardi RK. Lack of HHV-8 DNA sequences in sarcoid tissues of French patients. Chest. 1998;114(3):948-9.

65. Ishihara M, Ohno S, Ono H, Isogai E, Kimura K, Isogai H, Aoki K, Ishida T, Suzuki K, Kotake S, Hiraga Y. Seroprevalence of anti-Borrelia antibodies among patients with confirmed sarcoidosis in a region of Japan where Lyme borreliosis is endemic. Graefes Arch Clin Exp Ophthalmol. 1998;236(4):280-4.

66. Martens H, Zöllner B, Zissel G, Burdon D, Schlaak M, Müller-Quernheim J. Anti-Borrelia burgdorferi immunoglobulin seroprevalence in pulmonary sarcoidosis: a negative report. Eur Respir J. 1997;10(6):1356-8.

67. Lian W, Luo W. Borrelia burgdorferi DNA in biological samples from patients with sarcoidosis using the polymerase chain reaction technique. Chin Med Sci J. 1995;10(2):93-5.

68. Xu Z, Ma D, Luo W, Zhu Y. Detection of Borrelia burgdorferi DNA in granulomatous tissues from patients with sarcoidosis using polymerase chain reaction in situ technique. Chin Med Sci J. 1996;11(4):220-3.

69. Ishihara $M$, Ishida $T$, Isogai $E$, Kimura $K$, Oritsu M, Matsui $Y$, Isogai H, Ohno S. Detection of antibodies to Borrelia species among patients with confirmed sarcoidosis in a region where Lyme disease is nonendemic. Graefes Arch Clin Exp Ophthalmol. 1996;234(12):770-3.

70. Nilsson K, Påhlson C, Lukinius A, Eriksson L, Nilsson L, Lindquist O. Presence of Rickettsia helvetica in granulomatous tissue from patients with sarcoidosis. J Infect Dis. 2002;185(8):1128-38.
71. Svendsen CB, Milman N, Andersen CB, Rasmussen EM, Thomsen VØ, Krogfelt KA. Is sarcoidosis a rickettsiosis? An archival study. Scand J Infect Dis. 2011;43(5):349-53.

72. Puolakkainen M, Campbell LA, Kuo CC, Leinonen M, Grönhagen-Riska C, Saikku P. Serological response to Chlamydia pneumoniae in patients with sarcoidosis. J Infect. 1996;33(3):199-205.

73. Lyons DJ, Sinclair A, Smith HG, Mitchell DN, Dalgleish AG. Search for a retroviral cause for sarcoidosis: no evidence from peripheral blood studies. Eur Respir J. 1991;4(4):445-9.

74. Schupp JC, Tchaptchet S, Lützen N, Engelhard P, Müller-Quernheim J, Freudenberg MA, Prasse A. Immune response to Propionibacterium acnes in patients with sarcoidosis-in vivo and in vitro. BMC Pulm Med. 2015;15:75.

75. Zhou Y, Wei YR, Zhang Y, Du SS, Baughman RP, Li HP. Real-time quantitative reverse transcription-polymerase chain reaction to detect propionibacterial ribosomal RNA in the lymph nodes of Chinese patients with sarcoidosis. Clin Exp Immunol. 2015;181(3):511-7.

76. Yorozu P, Furukawa A, Uchida K, Akashi T, Kakegawa T, Ogawa T, Minami J, Suzuki Y, Awano N, Furusawa H, Miyazaki Y, Inase N, Eishi Y. Propionibacterium acnes catalase induces increased Th1 immune response in sarcoidosis patients. Respir Investig. 2015;53(4):161-9.

77. Ishige I, Eishi Y, Takemura T, Kobayashi I, Nakata K, Tanaka I, Nagaoka S, Iwai K, Watanabe K, Takizawa T, Koike M. Propionibacterium acnes is the most common bacterium commensal in peripheral lung tissue and mediastinal lymph nodes from subjects without sarcoidosis. Sarcoidosis Vasc Diffuse Lung Dis. 2005;22(1):33-42.

78. Jacob F. Could Borrelia burgdorferi be a causal agent of sarcoidosis? Med Hypotheses. 1989;30(4):241-3.

79. Edelson E. Isoniazid in the treatment of sarcoidosis; a preliminary report. J Invest Dermatol. 1953;21(2):71-4.

80. Israel HL, Sones M, Harrell D. Ineffectiveness of isoniazid and iproniazid in therapy of sarcoidosis. Am Rev Tuberc. 1953;67(5):671-3.

81. Holsinger RE, Dalton JE. Isoniazid therapy in cutaneous tuberculosis and sarcoidosis. J Am Med Assoc. 1954;154(6):475-81.

82. Chatterjee SC, Ghosh JC. Sarcoidosis treated with antituberculous drugs. J Indian Med Assoc. 1957;29(2):61-3.

83. Drake WP, Oswald-Richter K, Richmond BW, Isom J, Burke VE, Algood H, Braun N, Taylor T, Pandit KV, Aboud C, Yu C, Kaminski N, Boyd AS, King LE. Oral antimycobacterial therapy in chronic cutaneous sarcoidosis: a randomized, single-masked, placebo-controlled study. JAMA Dermatol. 2013; 149(9):1040-9.

84. Drake WP, Richmond BW, Oswald-Richter K, YU C, Isom JM, Worrell JA, Shipley GR. Effects of broad-spectrum antimycobacterial therapy on chronic pulmonary sarcoidosis. Sarcoidosis Vasc Diffuse Lung Dis. 2013;30(3):201-11.

85. Sheu J, Saavedra AP, Mostaghimi A. Rapid response of tattoo-associated cutaneous sarcoidosis to minocycline: case report and review of the literature. Dermatol Online J. 2014;20(8):6.

86. Steen T, English JC. Oral minocycline in treatment of cutaneous sarcoidosis. JAMA Dermatol. 2013;149(6):758-60.

87. Miyazaki E, Ando M, Fukami T, Nureki S, Eishi Y, Kumamoto T. Minocycline for the treatment of sarcoidosis: is the mechanism of action immunomodulating or antimicrobial effect? Clin Rheumatol. 2008;27(9):1195-7.

\section{Submit your next manuscript to BioMed Central and we will help you at every step:}

- We accept pre-submission inquiries

- Our selector tool helps you to find the most relevant journal

- We provide round the clock customer support

- Convenient online submission

- Thorough peer review

- Inclusion in PubMed and all major indexing services

- Maximum visibility for your research

Submit your manuscript at www.biomedcentral.com/submit 